\title{
Addressing the Middle-Income Trap: Experience of Indonesia
}

\author{
Aviliani ${ }^{1}$, Hermanto Siregar ${ }^{2} \&$ Heni Hasanah $^{3}$ \\ ${ }^{1}$ STIE Perbanas, Jakarta, Indonesia \\ ${ }^{2}$ Department of Economics, Faculty of Economics and Management, Bogor Agricultural University (IPB), \\ Indonesia \\ ${ }^{3}$ Department of Economics, Faculty of Economics and Management, IPB, Indonesia \\ Correspondence: Heni Hasanah, Department of Economics, Faculty of Economics and Management, IPB, Bogor \\ 16680, Indonesia. Tel: 62-251-862-2636. E-mail: heni_hasanah@yahoo.co.id
}

Received: December 16, 2013 Accepted: February 13, 2014 Online Published: March 31, 2014

doi:10.5539/ass.v10n7p163

URL: http://dx.doi.org/10.5539/ass.v10n7p163

\begin{abstract}
Middle-income trap (MIT) refers to a condition in which the middle-income countries are not able to follow the trajectory of an economic growth to achieve a new level as high-income countries. Using descriptive analysis, more than 30 countries are found to experience MIT including China and India. Some of countries in Africa are even experiencing low-income trap. Between 1970 and 2011 Indonesia was actually in a transition condition of low-income to middle-income economy. Indonesia has begun to face constraints that would inhibit the sustained growth, particularly on the supply side of the economy. It is better to do the anticipatory actions that can strengthen the economy's fundamentals in order to avoid MIT. The estimated regression model used in this study indicates that the increase in current national income is affected by the previous national income and the share of gross fixed capital formation to GDP. So, to avoid MIT, the government of Indonesia should prioritize on investment for developing growth centers as well as for improving human resources and technology application.
\end{abstract}

Keywords: middle-income trap, Indonesia, regression analysis, economic corridors

\section{Introduction}

\subsection{Problem of Middle-Income Trap: Global Perspective}

The economic development of countries has been more or less a long sequence from low income to middle income and, ideally, to high income. That is to follow the expected trajectory of growth. However, countries get stuck in the low or middle income groups for a long period of time and do not move up. In the other cases, the reversals sequence may be happen. Countries in the middle income group slide back to the low income group. That could happen because of some major adverse shocks. Kuznets (1971) and Felipe (2012) stated that Economic development itself is a very complex process that involves: (i) the transfer of resources (labor and capital) from activities of low productivity sector into activities of higher productivity sector; (ii) capital accumulation; (iii) industrialization and the manufacture of new products using new methods of production; (iv) urbanization; and (v) changes in social institution and beliefs.

Since the 1960s, rapid economic growth has pushed some economies to reach the level of middle income and high income categories. Meanwhile, some countries are still trapped in conditions of lower income or middle income groups. There are concerns that middle-income countries are difficult to get through the stages towards high income group. This is what is called the middle-income trap (MIT). There is no consensus yet about what causes a country to fall into a MIT, but Jitsuchon (2012) inferred that economic dynamism perhaps plays an important role. Based on World Bank, economies are divided according to 2011 Gross National Income (GNI) per capita, calculated using the World Bank Atlas method. The groups are, i) low income ( $\$ 1.025$ or less); ii) lower middle income (\$1.026 - \$4.035); iii) upper middle income (\$4.036 - \$12.475); and iv) high income (\$12.476 or more).

Trajectory of economic growth is expected from low income to the middle income and middle income to high income. MIT refers to a condition in which the per capita income of such country has grown insufficiently high that the economy of the country is becoming stuck or stagnant. As a result, the country has always been on the classification of middle-income. Figure 1 shows the distribution of the countries in the world based on the classification in period $1960-2008$. 


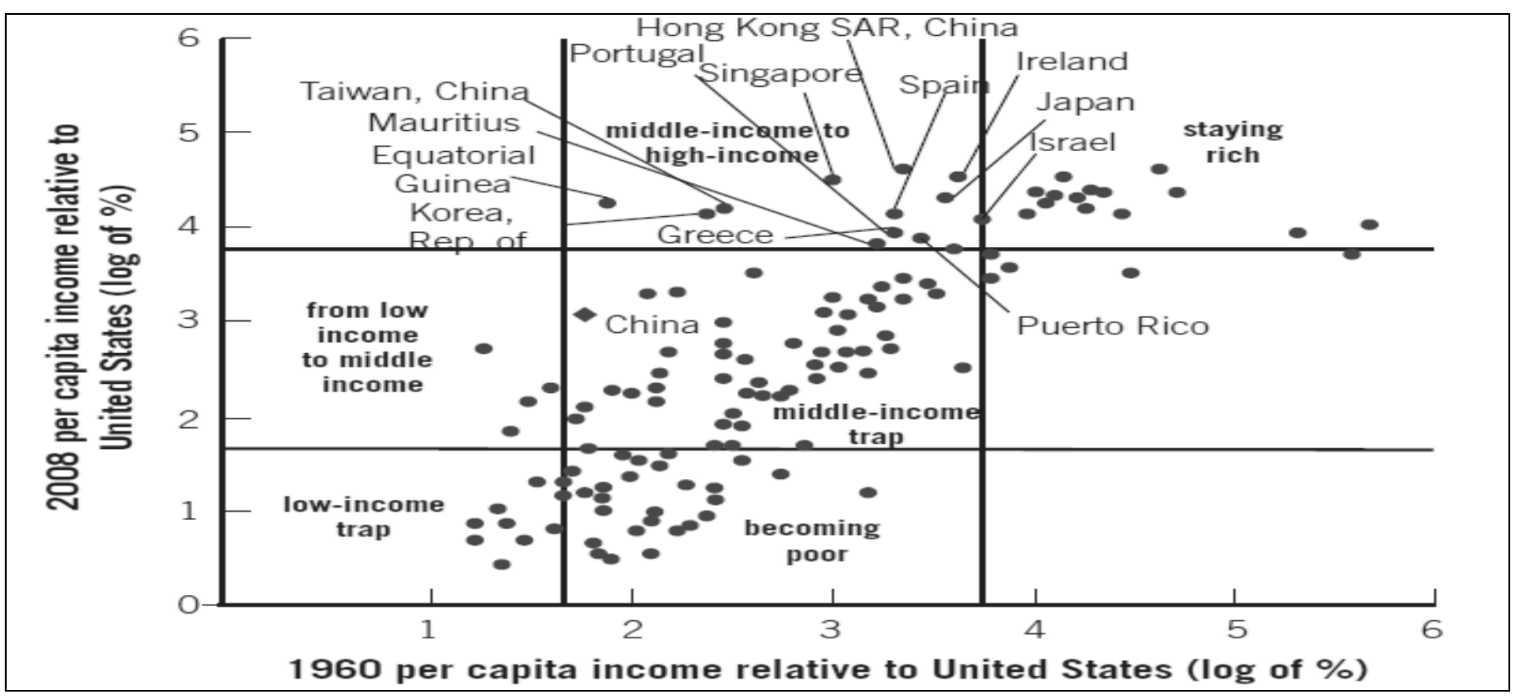

Figure 1. Middle income trap (1960-2008)

Source: World Bank, 2013

There are several countries that stuck on a position as middle income countries during 1960 to 2008, such as China, Brazil, Oman, and Malaysia. Surely there is a more severe condition in which some countries belong to the lower-income trap such as Burundi. There are also countries such as Niger and North Korea which experienced the condition of becoming poorer. In 1960 they were in the middle income group, while in 2008 both of those countries as well as several other countries belonging to the lower income groups. United States and Switzerland belong to the group of countries that are staying rich. While South Korea, Greece, Taiwan, and Israel fall into the category of countries that moved up from the middle income into a high income category. There are other East Asian countries that have made it into the high income group such as Singapore and Hong Kong.

\subsection{Objectives and Method}

The primary objective of this study is to see whether or not the Indonesian economy is now entering MIT. In addition, this study also analyzes the role of exports and investment for escaping the MIT.

Descriptive analysis is used to answer the first objective related to whether or not Indonesia has entered MIT. A multiple regression model is utilized to analyze the role of exports and investment, as well as the initial income (per capita GNI in 1970) on the current income, i.e. per capita GNI in 2011. The data used are of cross-sectional data from 86 countries in the world. Sampling is purely based on the availability of data sourced from the World Bank. The regression model used in this study is as follows:

$$
Y_{i}=\alpha_{0}+\alpha_{1} X_{1 i}+\alpha_{2} X_{2 i}+\alpha_{3} X_{3 i}+\alpha_{4} X_{4 i}+\alpha_{5} X_{5 i}+\alpha_{6} X_{6 i}+\alpha_{7} X_{7 i}+\varepsilon_{i}
$$

where $\mathrm{Y}$ is natural logarithm of per capita GNI in 2011; $X_{1}$ is natural logarithm of per capita GNI in 1970; $X_{2}$, $X_{3}$, and $X_{4}$ respectively are export share to GDP year 1980,1990, and 2000; $X_{5}, X_{6}$, and $X_{7}$ respectively are gross fixed capital formation share to GDP year 1980, 1990, and 2000; and $\varepsilon$ is the error term. At this analysis we only focus on the role of exports and investment on affecting per capita income by taking certain time points in each decade.

\section{Does Indonesia Face Middle-Income Trap?}

Figure 2 shows results of updating the data utilized in Figure 1 to become of 1970 - 2011. It can be seen from Figure 2 that China, Malaysia, and Brazil are still in a condition of MIT. Two ASEAN countries namely Philippines and Thailand also experience MIT. Nepal being one of the countries that experiences a low-income trap, while Kenya and Zimbabwe experience to become poorer. 


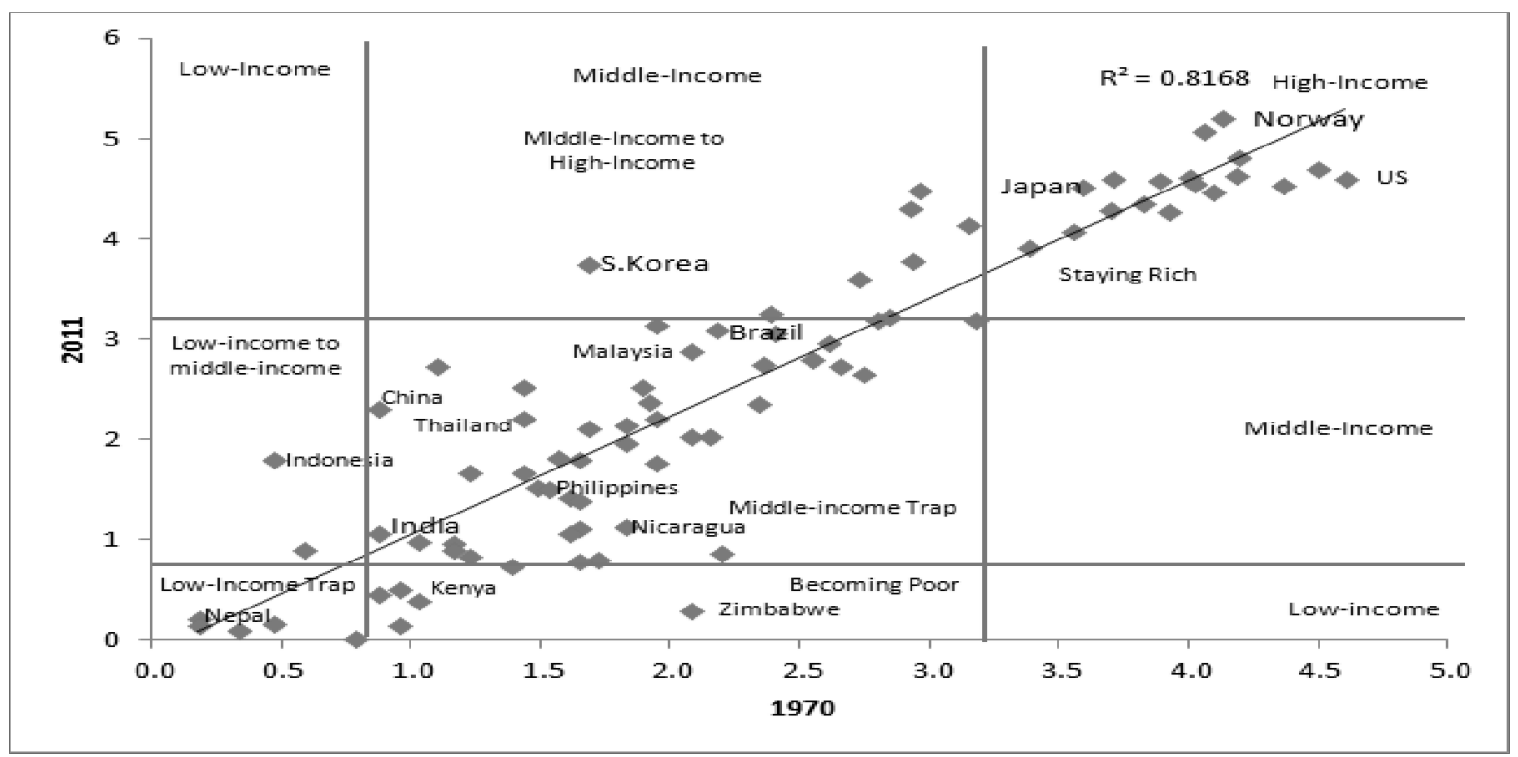

Figure 2. Middle income trap (1970-2011)

Data Source: World Bank, 2012 (processed)

Table 1 shows more detail of countries in each group. More than 30 countries are trapped in middle-income group. All countries which are classified as becoming poorer economies are located in the African continent. Four of the five countries that are in conditions of low-income trap are also in the African continent as one country in the continent of Asia. While all countries included in the category of staying rich are members of the Organization for Economic Co-operation and Development (OECD).

Table 1. Classification based on countries position in 1970 and 2011

\begin{tabular}{|c|c|c|c|c|c|c|c|}
\hline \multicolumn{2}{|r|}{$\begin{array}{l}\text { Becoming } \\
\text { Poor }\end{array}$} & $\begin{array}{c}\text { Low Income } \\
\text { Trap }\end{array}$ & $\begin{array}{c}\text { Middle Income } \\
\text { Trap }\end{array}$ & $\begin{array}{c}\text { Low income } \\
\text { to middle } \\
\text { income } \\
\end{array}$ & $\begin{array}{l}\text { Middle income } \\
\text { to high income }\end{array}$ & \multicolumn{2}{|r|}{ Staying rich } \\
\hline 1. & Kenya & Gambia & 1. China & 1. Indonesia & 1. South & 1. & United States \\
\hline 2. & Zimbabwe & Rwanda & 2. Bostwana & 2. Lesotho & Korea & 2. & Norway \\
\hline 3. & Togo & Nepal & 3. Thailand & & 2. Saudi & 3. & Luxembourg \\
\hline 4. & Chad & 4. Mali & 4. Philipina & & Arabia & 4. & Denmark \\
\hline 5. & Benin & Burkina & 5. Sri Lanka & & 3. Spain & 5. & Sweden \\
\hline & & Faso & 6. India & & 4. Singapore & 6. & Australia \\
\hline & & & 7. Malaysia & & 5. Hongkong & 7. & Netherlands \\
\hline & & & 8. Brazil & & 6. Portugal & 8. & Belgium \\
\hline & & & 9. Seychelles & & & 9. & Canada \\
\hline & & & 10. Costa Rica & & & & Japan \\
\hline & & & 11. Gabon & & & 11. & Finland \\
\hline & & & 12. Mexico & & & 12. & Austria \\
\hline & & & 13. Panama & & & 13. & Greece \\
\hline & & & 14. South & & & 14. & Israel \\
\hline & & & Africa & & & 15. & Italy \\
\hline & & & 15. Peru & & & 16. & United \\
\hline
\end{tabular}



16. Fiji
17. Belize
18. Guatemala
19. Zambia
20. Nicaragua
21. Papua NG
22. Ghana
23. Nigeria
24. Egypt
25. Paraguay
etc.

Kingdom

17. Iceland

During 1970 - 2011, Indonesia was actually in a transition condition of low-income to middle-income economy. Indonesia's economic growth has increased around four-fold during the last two decades, which successfully moves the economy up from the low to the middle income category. It has been shown above that Indonesia has not entered into a middle-income trap. However, there is a concern about it due to relatively slow increase in per capita GDP in more recent years. Indonesia per capita GDP of 1972 to 2011 was lower than those of Malaysia, Thailand, and Philippines (Figure 3). For Indonesia and Thailand, financial crisis in 1997/1998 cut per capita real income significantly and only back to the same level after about 10 years.

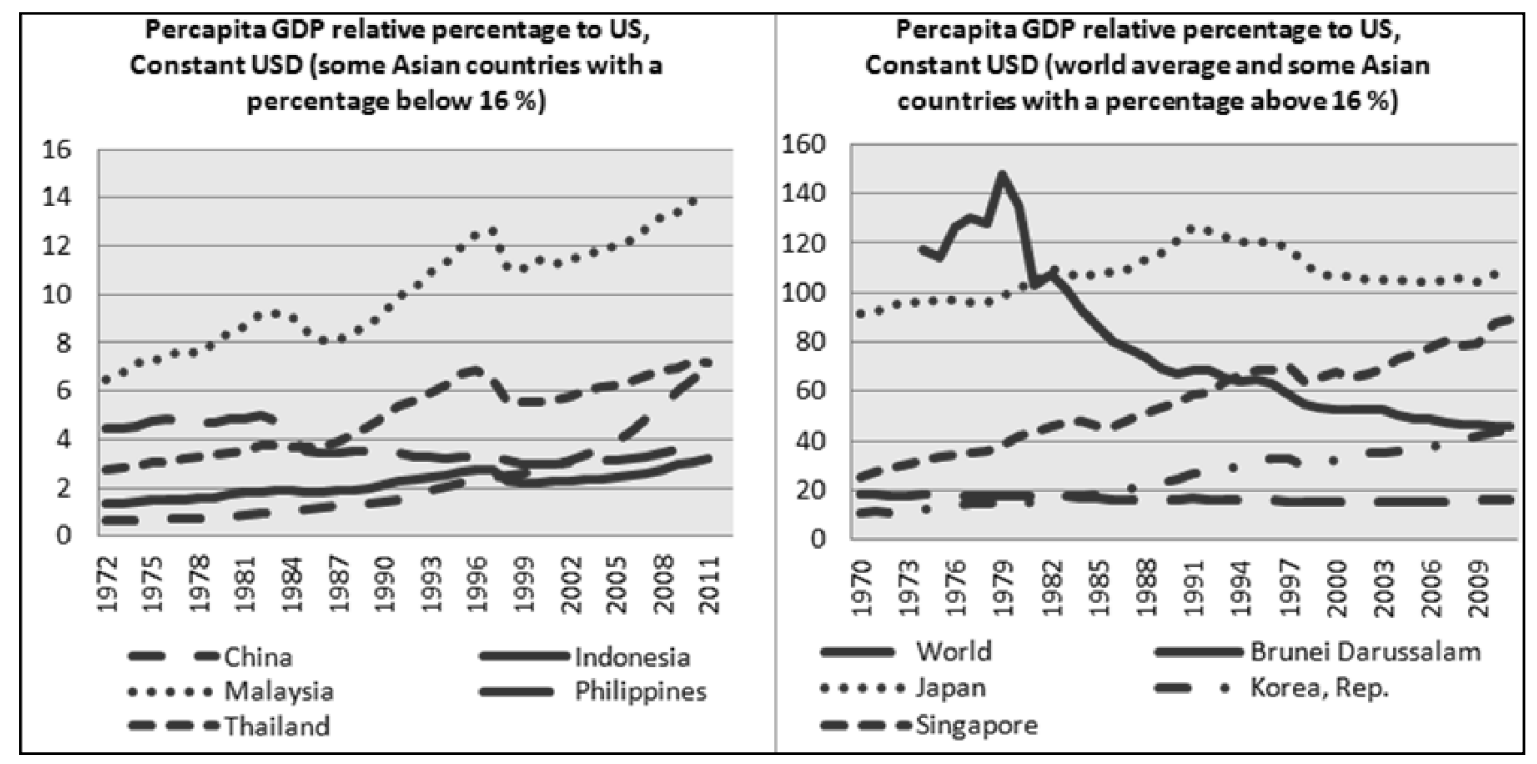

Figure 3. Comparison: Indonesia and some Asian countries

Data Source: World Bank, 2012 (processed).

\subsection{Potential Problems that May Put Indonesia into MIT}

Some problems as the cause of the concern are as follows. Indonesia began to face constraints that will inhibit the sustained growth. Actually, on the demand side, the potential growth of Indonesia is still very large due to its population of almost 250 millions, but on the supply side it began to face some drawbacks. First, agricultural production will be difficult to increase in order to meet the rising demand if Indonesia continues to maintain the way to manage agriculture as it is today due to stagnation in agricultural commodity yields. Productivity and income of farmers will remain low, causing difficulties in alleviating rural poverty and in narrowing income disparities between farmers and non-farmers. Modernization and industrialization of the agricultural sector is necessity in order to increase productivity. Second, slow growth of the number of high skilled workers caused slower growth of labor productivity and of the overall economy. Third, stronger labor union has tended to significantly increase minimum wage in continuous manner raising the costs and lowering the competitiveness 
of agricultural products. And last problem is slow development of agricultural infrastructure which prohibits efforts to improve efficiency.

If viewed from the Global Competitiveness Ranking, it can be seen that the infrastructure progressing quite slow (Table 2). So is the case for health and primary education. Higher education, technology, and innovation progressing even slower than the averages, resulting in backward movement in terms of the ranking. That is also the case for the institution pillars. Very low ranking occurred in pillar of efficiency in the labor market. This is one indicator of many things that should be addressed in the Indonesian labor market. But with regard to performance of macroeconomy condition, there has been a significant increase in terms of the ranking, i.e. from the 57th rank in 2006 to the 25 th in 2012 coupled with a high ranking on the pillars of domestic and foreign market size.

Table 2. Global competitiveness ranking of Indonesia

\begin{tabular}{llcc}
\hline \multicolumn{1}{c}{ Subindexes } & \multicolumn{1}{c}{ Pillars } & 2006 Ranking & 2012 Ranking \\
\hline Basic Requirements & Institution & 52 & 72 \\
& Infrastructure & 89 & 78 \\
& Macroeconomy & 57 & 25 \\
& Health and primary education & 72 & 70 \\
Efficiency Enhancers & Higher education and training & 53 & 73 \\
& Goods Market Efficiency & Market efficiency $=27$ & 63 \\
& Labor Market Efficiency & Market efficiency $=27$ & 120 \\
& Financial Market Development & - & 70 \\
& Technological readiness & 72 & 85 \\
Innovation and & Market Size & - & 16 \\
sophistication factors & Business sophistication & 42 & 42 \\
\hline
\end{tabular}

Source: World Economic Forum (2006 and 2012)

These slacks do not mean that everyone is pessimistic on the economic prospects. There are also some optimistic views that MIT is not going to happen in Indonesia. The Indonesian economy has grown rapidly with average growth rate of 7.99 percent during 1990-1996. During the crisis period (1997-1999) the average growth rate decreased sharply to -2.55 percent, but then increased again to above 6 percent from 2010 to now on causing Indonesia to reach the status of a lower middle-income country by the World Bank classification. GDP in 2012 amounted to 917 billion dollars and is projected to be 1,041 billion dollars in 2013. Based on current USD, per capita GDP of Indonesia increase from $\$ 81.6$ in 1970 to $\$ 3,695$ in 2012. In addition, Indonesia's economic growth in 1970 and 2011 reached the level of more than the average growths of the middle income group.

In 2000, Indonesia is the 33rd largest country in the world in term of GDP with economic growth rate of 4.9 percent and ranked 64th by global competitiveness ranking. Structure of the economy was dominated by manufacturing sector with share about 28.8 percent and the export value of $\$ 68$ billion. Currently, Indonesia is the 16th largest economy in the world with economic growth of 6.1 percent with an average economic growth of 2000-2010 is the third highest in the world after China and India. However, the inflation rate in 2011 was still relatively high ( 8.4 percent), although in the following year had dropped to about 4.3 percent. In addition, Indonesia's Global competitiveness was ranked 50th and entered the second phase of the efficiency driven stage. The manufacturing sector is still the largest share of structure of the economy with a decreased share (24.6 percent).

Optimism is growing longer by the McKinsey Global Institute (2012) study results. According to that, Indonesia in 2030 will be the 7th largest country in the world which is made up of 135 million people as a consuming class. Then, 71 percent of the urban population produces about 86 percent of GDP. In that year, Indonesia will need about 113 million skilled workers. In terms of market opportunity, there are about 1.8 trillion dollar market opportunity in consumer services, agriculture and fisheries, resources, and education. 


\subsection{Analysis of Factors Affecting National Income as an Essential Determinant of Avoiding MIT}

In this section we identify export and investment roles on determining per capita national income, which is necessary for avoiding MIT by using the multiple regression analysis. Estimation results of regression model are as follows (Note 2):

$$
\begin{gathered}
Y_{i}=-0.520+1.160 X_{1 i}-0.005 X_{2 i}+0.004 X_{3 i}+0.001 X_{4 i}+0.040 X_{5 i}+0.001 X_{6 i}+0.050 X_{7 i} \\
(-1.34) \quad(24.54) \quad(-0.79)
\end{gathered}
$$

$\mathrm{R}^{2}=0.89$ (Figures in the parentheses are the t-statistics)

Results of the regression model suggest that explanatory variables that significantly affect the per capita GNI in 2011 are a previous per capita GNI (year 1970, $X_{1 i}$ ) and the share of investment (gross fixed capital formation) to GDP in $1980\left(X_{5 i}\right)$ and $2000\left(X_{7 i}\right)$. An increase in per capita GNI (in 1970) by 1 percent would lead to increase in Per capita GNI in 2011 by 1.16 percent. While 1 percent increase in the share of investment (in year 1980 and 2000) would increase current per capita GNI by 0.04 to 0.05 percent. In this study we found that the share of exports to GDP has insignificant effect and small elasticity value.

These results do not mean that trade policy to boost exports is not important, but this suggests that the government should focus more on creating policies for investment development. Therefore, Indonesia should prioritize its development in years to come to invest more on the infrastructure and other factors affecting its investment climate which are necessary for developing new growth sources of the country, which will be explained in the next section, as well as for improving human resources and technology application.

\subsection{Avoiding MIT for Indonesia}

It has been explained in the previous section that Indonesia is among the lower middle income group and had successfully passed the trajectory of growth from his previous position as a low income country. Despite this prospect, it is better to be careful and do anticipatory actions that can strengthen economic fundamentals in order to avoid MIT. To avoid MIT, the government must continue to work in order to fulfill the rapid increases in its middle income demand for better products and services. It is also required for the country to develop at a faster speed quality of human resources, technology including the ICT, and infrastructure which stated by some researcher such as Aiyar, Duval, Puy, Wu, \& Zhang (2013) and Agenor, Canuto, \& Jelenic (2012). According to Jankowska, Nagengast, \& Perea (2012) technology can be a main recipe for upgrading towards higher value industries which will eventually converge the income. Reforming labor markets and enhancing innovation as stated by Agenor, et al. (2012) are also some homework for every government to counteract MIT. All of these require investment which is found more important to be prioritized as significant determinant of per capita income. More investment needed for accelerating and expanding economic development to support its transformation into a developed country. For that, the country needs new growth centers.

Based on The Master Plan of Acceleration and Expansion of Indonesia Economic Development (MP3EI) 2011-2025, Indonesia develop six corridors of economic growth each of which contains new growth centers. It is unique to Indonesia being an archipelagic country with around 17,000 islands. MP3EI provides the building blocks to transform Indonesia into one of the 10 major economies in the world by 2025 . To achieve this, real economic growth must reach 7 - 9 percent per year, on an ongoing basis. MP3EI integrate 3 main elements:

1) Developing the regional economic potential in 6 (six) Indonesia Economic Corridors: Sumatra Economic Corridor, Java Economic Corridor, Kalimantan Economic Corridor, Sulawesi Economic Corridor, Bali - Nusa Tenggara Economic Corridor, and Papua - Kepulauan Maluku Economic Corridor;

2) Strengthening national connectivity locally and internationally;

3) Strengthening human resource capacity and national science \& technology to support the development of main programs in every economic corridor.

Acceleration and expansion of Indonesia's economic development are based on the development of existing and creating new growth centers. This development strategy is essentially an integration of the sectoral and regional development approaches. The purpose of developing new growth centers is to optimize agglomeration advantages, to explore regional strengths, and to reduce spatial imbalance of economic development throughout the country. As part of this strategy, each region will develop their specific local products.

The development of economic growth centers will be managed through the development of industrial clusters and special economic zones. This will be accompanied with increased and improved connectivity between the 
centers of economic growth (major cities) and main industrial clusters supported by improved infrastructures including roads, seaports, airports, power, water, and other related infrastructures. In all, growth centers and connectivity are the building blocks of Indonesia Economic Corridors.

In order to accelerate and expand economic development, it is necessary to create new economic regions outside of the existing economic growth centers. The government will provide special incentives to support the development of these centers, especially those located outside of Java, and particularly to businesses that are willing to finance the construction of supporting facilities and infrastructures. The aim of providing such incentives is to encourage businesses to build long term perspectives in the development of the new economic growth centers.

Development of economic corridors is similar to regional development aimed at creating an integrated and sustainable economic base. However, the developments of the six economic corridors give greater emphasis to economic development as follows:

1) Indonesia Economic Corridor will emphasize the increase of productivity and value-adding on natural resource management through the expansion and creation of a sustainable upstream and downstream activity chain;

2) Indonesia Economic Corridor will focus on diverse and inclusive economic development, which connects corridors with other regions to develop opportunities based on local potential and specialization;

3) Indonesia Economic Corridor emphasize sectoral and regional development synergies to enhance national, regional and global comparative and competitive advantages;

4) Indonesia Economic Corridor emphasizes integrated economic development between transportation and logistics, as well as communications and information systems to open regional access;

5) Indonesia Economic Corridor will be supported with fiscal and non-fiscal incentives, ease of regulation, licensing, and optimum public services from Central and Local Governments.

Table 3. Matrix of six economic corridors of Indonesia

\begin{tabular}{ll}
\hline \multicolumn{1}{c}{ Corridor } & \multicolumn{1}{c}{ Theme } \\
\hline Sumatra & Centre for Production and Processing of Natural Resources and As Nation's Energy \\
& Reserves \\
Java & Driver for National Industry and Service Provision \\
Kalimantan & Centre for Production and Processing of National Mining and Energy Reserves \\
Sulawesi & Centre for Production and Processing of Agricultural Plantation, Fishery, Oil and gas, \\
& and Mining \\
Bali-NT & Gateway for Tourism and National Food Support \\
Papua-Kep. Maluku & Centre for Development of Food, Fisheries, Energy, and National Mining \\
\hline
\end{tabular}

Source: MP3EI (2011)

Table 3 shows the distribution of six economic corridors. The corridors are Sumatra, Java, Kalimantan, Sulawesi, Bali-Nusa Tenggara (NT), and Papua-Kep. Maluku. Each corridor has played economic activities which are designed based on the inherent potential and strategic value of each of the corridors. Main economic activities in Sumatra are palm oil, rubber, coal, steel, shipping, Sunda Straits National Strategic Area. Meanwhile, main economic activities in Java such as food and beverages, textiles, transportation equipment, shipping, ICT, Jabotabek Area, and defense equipment. In Kalimantan, main economic activities are steel, bauxite, palm oil, coal, oil and gas, and timber. Main economic activities in Sulawesi are nickel, food, agriculture, oil and gas, cocoa and fishery. Main economic activities in Bali-NT include tourism, animal husbandry and fishery. Main economic activities in Papua-Kep. Maluku are nickel, copper, food, agriculture, oil and gas, and fishery.

One of the implementation strategies of the MP3EI is to strengthen national connectivity. As represented in Figure 4, the integration of the four components of national connectivity will be formulated into a national connectivity vision, which is "locally integrated, globally connected". Locally integrated is a connectivity system to support an effective and efficient movement of goods, services, and information, within the country. Therefore, 
the integration of transportation nodes, intermodal connectivity and communication networks are important elements to strengthen local and national connectivity. However, globally connected is a connectivity system aimed at connecting the country with the rest of the world via a system of global connectivity through a network of international gateway/exchange located at the major seaport and airport supported by custom and trade facilities.

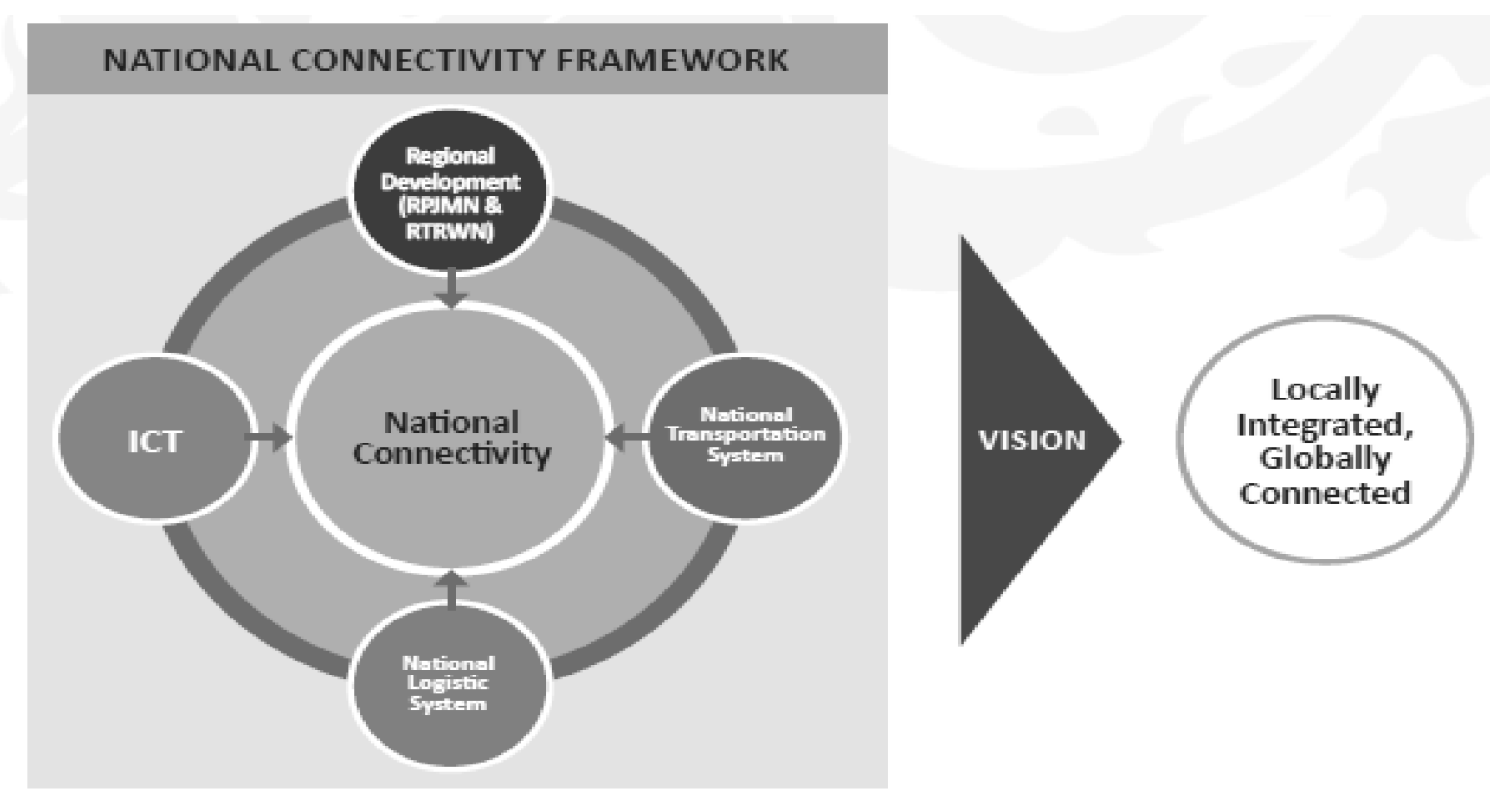

Figure 4. National connectivity vision

Source: MP3EI (2011)

\section{Conclusion and Implications}

\subsection{Conclusion}

A problem of MIT has become its own concerns for any country, especially for developing countries, including Indonesia. The condition of being in the MIT has become to be one indication that the economy is not on the right trajectory of growth. Constraints on the supply side potentially may plunge Indonesia into MIT. The main problem is slow infrastructure development. In terms of human resources, the slow growth of skilled workers can lead to slower labor productivity growth and also have final adverse impact on economic growth. Stagnancy of yield of the crops prohibits income of farmers to significantly increase, complicates the process of poverty reductions, and ultimately widens the income disparity between farmers and non-farmers.

Based on the data, in the range of four decades, Indonesia is not included in MIT condition yet. Indonesia had progressed from the classification of low income to lower middle income. This means that Indonesia is on the right trajectory of growth but the MIT still need to be anticipated. Related to the role of exports and investments that can avoid a country from entering MIT, the cross-section regression results indicate that investment has more significant role in increasing per capita GNI compared to exports. This suggests that investment promotion can become a key strategy to anticipate or avoid from MIT. This does not mean for the government to abandon trade policies, because it still can be a companion strategy to boost the economy especially after the investment has successfully produced better quality and more competitive products from the potential economic corridors of Indonesia.

\subsection{Implications}

The Indonesian economy is not in the MIT condition, because the country has just entered the middle-income criteria. The implication, several years ahead, MIT problem remains a challenge for Indonesia. The favorable investment climate should be improved continuously. Currently, investments are expected to not only focus on public investment but also by involving the private sector to play a bigger role. The Public - Private - Partnership (PPP) program is expected to be not only a master plan but also can be implemented more quickly. Policies that could hinder the expansion of private investment need to be evaluated and then removed swiftly. 
As lessons learned, Singapore as the neighboring country of Indonesia is one of the successful countries related to realization of PPP. Singapore's success stems from several aspects, such as skilled workforce, an English-speaking population and an ability to attract investors due to a reputation of low levels of corruption. Some dominant best practice of Singapore in PPPs as stated by Strategic Asia (2012) are: i) Existence of a centralized unit for coordination related to policies and regulatory frameworks for both the government and investors; ii) Singapore vision of establishing itself as a centre of excellence in the region, as driven factors in to implement PPP projects; iii) PPP projects was started by traditional infrastructure projects and gradually moved towards much larger projects; iv) A clear division of roles and risk allocation between the public and private sector; v) Structure of PPP tender helped by a team of advisors and experts, including experienced professionals; and vi) Good discipline for targeted deadlines, so no added costs burden the private sector.

From the lessons learned, the main thing that driven good implementation of PPP is a political will. According to Ohno (2009), he stated that a new style of leadership was needed to build a better mindset as well as political will. The lack of existence of political will can hamper implementation of a program even though the design of that is very excellent. In addition, the keyword of a good PPP implementation from the best practice is coordination. In general term as suggested by Woo (2009), for avoiding and escaping MIT, reform in many areas is needed urgently.

\section{References}

Agenor, P. R., Canuto, O., \& Jelenic, M. (2012). Avoiding Middle-Income Growth Traps. Economic Premise, (98), 1-7.

Aiyar, S., Duval, R., Puy, D., Wu, Y., \& Zhang, L. (2013). Growth Slowdowns and the Middle-Income Trap. IMF Working Paper, No. 13/71, pp. 1-63. http://dx.doi.org/10.5089/9781484330647.001

Coordinating Ministry for Economic Affairs and Ministry of National Development Planning. (2011). Master Plan for Acceleration and Expansion of Indonesia Economic Development 2011 - 2025. Coordinating Ministry for Economic Affairs, Republic of Indonesia.

Felipe, J. (2012). Tracking the Middle-Income Trap: What is it, Who is in It, and Why? ADB Economics Working Paper Series, (306), 1-38.

Jankowska, A., Nagengast, A. J., \& Perea, J. R. (2012). The Middle-Income Trap: Comparing Asian and Latin American Experiences. Policy Insights, (96), 1-2.

Jitsuchon, S. (2012). Thailand in a Middle-Income Trap. Thailand Development Research Institute (TDRI) Quarterly Review, 27(2), 13-20.

Kuznets, S. (1971). Economic Growth of Nations: Total Output and Production Structure. Cambridge: Belknap Press of Harvard University Press. http://dx.doi.org/10.4159/harvard.9780674493490

McKinsey Global Institute. (2011). Big Data: The Next Frontier for Innovation, Competition, and Productivity. McKinsey \& Company.

McKinsey Global Institute. (2012a). Manufacturing the Future: The Next Era of Global Growth and Innovation. McKinsey \& Company.

McKinsey Global Institute. (2012b). The Archipelago Economy: Unleashing Indonesia's Potential. McKinsey \& Company.

Ohno, K. (2009). Avoiding the Middle-Income Trap: Renovating Industrial Policy Formulation in Vietnam. ASEAN Economic Bulletin, 26(1), 25-43. http://dx.doi.org/10.1355/AE26-1C

Strategic Asia. (2012). PPP (Public-Private Partnership) in Indonesia: Opportunities from the Master Plan. Prepared by Strategic Asia for the UK Foreign Commonwealth Office.

The World Bank. (2013). China 2030 Building a Modern, Harmonious, and Creative Society. Development Research Center of the State Council, the People's Republic of China. Washington DC.

Woo, W. T. (2009). Getting Malaysia Out of the Middle-Income Trap. University of California, Davis.

World Economic Forum. (2006). The Global Competitiveness Report 2006-2007. The World Economic Forum.

World Economic Forum. (2012). The Global Competitiveness Report 2012-2013. The World Economic Forum.

\section{Notes}

Note 1. Most part of this paper was presented at The Forum of East Asia-Latin America Cooperation (FEALAC) 
Seminar on "Experience of FEALAC countries in Transforming Growth Model towards Sustainable Development", Hanoi, Vietnam, 6 June 2013.

Note 2. The usual econometric testing have been conducted, the results of which suggest that the model is free from violations of the OLS assumptions, including of autocorrelation and heteroscedasticity.

\section{Copyrights}

Copyright for this article is retained by the author(s), with first publication rights granted to the journal.

This is an open-access article distributed under the terms and conditions of the Creative Commons Attribution license (http://creativecommons.org/licenses/by/3.0/). 